DOI 10.14746/ssp.2018.4.5

\title{
Beata PająK-PatKowsKa
}

Adam Mickiewicz University in Poznań

ORCID: 0000-0002-6509-8067

Jaroslava PospíšilLová

Czech Academy of Sciences in Praha

ORCID: 0000-0002-9226-2547

\section{Czech and Polish understanding of democracy}

\begin{abstract}
The paper attempts to analyze the results of the European Social Survey Round 6 (2012, 2013), focusing on the section related to how democracy is understood in Poland and in the Czech Republic. The most interesting issue encompassed the differences in how democracy is defined in the two countries and the outcomes these differences produce in terms of the perceived legitimacy of the system, as well as demographic factors that correlate with differences in the understanding of democracy in both surveyed groups. Statistical analyses carried out in the paper indicated the presence of different definitions of democracy formulated in Poland and in the Czech Republic (the Czechs gave stronger emphasis to the liberal aspect of democracy, whereas Poles stressed its social aspects more). Nevertheless, the relationship between the definition of democracy and the perceived level of legitimacy of the democratic system (for dispersed and specific legitimacy alike) were found to be relatively weak, as was the case of the relationship between the understanding of democracy, system legitimacy and socio-demographic factors. The only factor found to be significant for the perceived level of legitimacy of the democratic system concerned the level of satisfaction with one's own material situation.
\end{abstract}

Key words: understanding of democracy, democracy, Poland, Czech Republic

\section{Introduction}

The purpose of this article is to analyze the results of research carried out under the European Social Survey in the part referring to the understanding of democracy in Poland and the Czech Republic. We are interested in the differences between the definition of democracy in the two countries and their consequences for the legitimacy of the system, as well as demographic factors influencing the way in which democracy is understood in the two countries concerned. We assume that the differ- 
ences between the two countries, related to their respective experiences with the democratic system and its operation, will translate into a different understanding of the concept of democracy (in the sense of associations with this system) (hypothesis 1). We also assume that the conception of democracy will translate into the perceived legitimacy of the democratic system (hypothesis 2). We also assume differences in definitions of democracy related to gender, material situation, place of residence and education.

\section{Theoretical background}

New democracies with weak civil society have to face growing levels of distrust and political apathy. Some scholars name this the 'post-honeymoon effect', which is caused by naive expectations being shattered (Inglehart, Catterberg, 2002). But to explain these processes only in terms of unfulfilled expectations and democratic 'immaturity' may be naive as well (Mlejnek, 2015). In the first years after regime change, legitimacy was based upon the difference between the old and new regime, but as time goes on, legitimacy is increasingly based on the new regime's effectiveness. The legitimacy of democracy and the effectiveness of its institutions are inseparable (Karp, Banducci, Bowler, 2003). Democracy's weakness lies in its inability to fulfill all of citizens' expectations. One of the consequences of this ineffectiveness is the low level of support for democracy in opinion polls. While in Poland the number of respondents who consider democracy to be the best system of government has been growing and has moved well above the threshold of $60 \%$ (CBOS, 2018), in the case of the Czech Republic, although an upward trend can also be observed, the highest level of support reached 56\% in 2018 (CVVM, 2018). This, together with low level of democratic knowledge (understanding and support for basic democratic values), may lead people to be unfazed by undemocratic alternatives (Svolik, 2013). The issue of accepting democratic values is undoubtedly one of the key issues in a democratizing country. The broader and deeper support for democracy runs among the citizenry, the higher the stability of democratic institutions is (Dahl, 2001).

In Easton's classic model of political support, support is conceptualized as a behavior that is based on certain individual attitudes. Stronger support for democratic rules is expressed by societies where this support 
is based on the values of political and civil liberties. If we examine the support base of a democratic regime, we should also address the importance of democratic values.

Countless definitions and theories of democracy can be found in the literature, from the time of the ancient philosophers such as Plato and Aristotle through Rousseau, Mill and Dahl. As Thomassen points out (1998), it is possible to divide the academic debate on the definition of democracy into two basic camps, individualistic and collectivist; the first defines democracy as the rule of law, whereas the second defines democracy as rule by the people. The essence of the whole dispute is the distinction between two fundamental democratic values - freedom and equality. According to previous research (Baviskar, Malone, 2004; Kornberg, Clarke, 1994; Miller, Hesli, Reisinger, 1997), similar ambiguity can also be found in public opinion. This means that different people understand democracy in different ways.

This may be important for the level of support for democracy within a society. We distinguish two dimensions of political support - diffuse (support for democracy as the only game in town), and specific (support for the regime people live under, influenced by the effectiveness of democratic institutions) (Easton, 1975).

\section{Previous research}

The question of the understanding of democracy in the Czech Republic is limited to some marginalized ideas by political scientists. Perhaps the most extensive study is the book by Pat Lyons (2013), which examines, alongside attitudes to citizenship, attitudes to democracy, and tracks their development between 1968 and 2008. Previous research on attitudes towards democracy in Czech society supported the vision of democracy in the liberal sense; people stressed personal liberties as the most important part of democracy (Brokl, Seidlová, Bečvář, Rakušanová, 1999; Lyons, 2013; Mansfeldová, 2006). Patterns of political attitudes regarding democracy based on the experience from the First Czechoslovak Republic (1918-1938) were still visible in citizens' opinions in 1968 and 1990. Therefore, it would be rational to expect growing levels of support for the social dimension of democracy after forty years under communist rule (Neundorf, 2010). However, we found no evidence of this in the data. On the other hand, we found strong evidence for the role played by 
the Opposition Agreement (signed between the two biggest parties, the conservative ODS and social-democratic CSSD in 1998) on citizens' political attitudes. This agreement is thought to be one of the most important reasons behind decreasing levels of specific support and growing political disaffection (Linek, 2016). The roots of the political disaffection of Czech citizens, according to Linek, must be sought in the political events of 1997-2000 (Linek, 2016), after which the drop in pro-democratic attitudes of the society also occurs. More evidence can be found in previous surveys examining support for a democratic regime, for example, Mishler and Rose (1994, 1996, 2002), which dealt with the issue comparatively with other post-communist countries. In 1998, the Czechs showed a high level of support for the democratic regime and democratic rules (Rose, Shin, 2001), and only the level of specific support (assessing how the current regime/government is working) was lower. If we monitor the development of the legitimacy of the democratic regime, as measured by the question of whether democracy is the best system of governance, we can see a consistent negative trend, with the most significant drop in support occurring after 2000 (Kunštát, 2014). In the last fifteen years, the level of support for democracy as the best system of governance amongst the Czech public was only around $50 \%$, with the lowest level being reached in 2012 (only 42\%). Conversely, this year (2018) it reached 56\%, the best result since 2004 (CVVM, 2018).

In the Czech Republic, democracy is more often supported by women than men; furthermore, age and education also show correlation with support for democracy. In the case of age, support for democracy declines with age (the lowest level of support is among people aged around 60 years: $41 \%$ ). Education correlates positively with support for democracy, i.e. the highest level of support is found in people with higher education and the lowest in people with basic education. Higher levels of support for democracy can also be found among people with higher incomes, and in urban areas. From the point of view of political orientation, it is certainly not surprising that support for democracy is highest among right-wing voters and lowest among the supporters of the communist party, the KSCM. Interestingly, we find that the electoral base of the social-democratic CSSD is more often in favor of authoritarian government, while KSCM voters are more typically ambivalent. This phenomenon can be reflected in particular by the fact that the KSCM has never participated in government since 1989, despite its considerable electoral support. 
These results can be compared to the results of Polish research on the understanding of democracy and expectations towards the democratic system. This type of research was conducted both by nationwide centers for surveying public opinion on representative samples, and as part of academic research conducted on smaller samples, sometimes of a deliberate nature, which, however, give a more detailed insight into the attitudes of citizens.

Regarding the first type of research, the results of periodical surveys conducted by Polish Public Opinion Research Center (CBOS) may be indicated. The last measurement took place in 2017 and allows changes in attitudes and understandings of democracy in Poland since 1992 to be followed. Analysis of the results suggests that the level of support for the statement: "Democracy has an advantage over all other forms of government" ranged between 52\% (in 1992) and 74\% (at the end of 2007), and in 2017 stood at 66\%. Demographic variables such as education, place of residence or income level correlate with variations in the level of support for democracy to a certain extent. Better educated people living in large agglomerations and people with higher salaries tend to have more pro-democratic attitudes than less educated people living in smaller towns and earning less. On the other hand, political views defined on a left-right axis do not show differences in attitudes towards democracy. However, it should be noted that in Poland a relatively large number of people agree with the statement: "Sometimes undemocratic governments are better than democratic ones." Although support for this statement has fallen in the last year to its lowest level in history, it is still very high, currently standing at $28 \%$. It is worth remembering, however, that the highest level was recorded in 2005 $(52 \%)$, and in the analyzed period the average support for this statement was $37 \%$.

One positive phenomenon observed in the research concerns a decline in the level of political alienation, diagnosed on the basis of support for the statement: "For people like me, it does not really matter whether the government is democratic or undemocratic." Currently, it stands at 28\%, while in 2015 it was 40\%. For this type of attitudes, education and income levels were important - people with primary, vocational or middle school education, residents of small towns and those with lower incomes expressed greater levels of alienation. On the other hand, the level of dissatisfaction with democracy in Poland is high - in 2017, it amounted to $52 \%$, and in the analyzed period there were years when the dissatisfaction 
rate reached $70 \%$ (e.g. in 2003). In this case, less-educated respondents, rural residents, people with lower incomes and the young tend to be more satisfied.

However, the way in which the concept of democracy is understood was much less the subject of CBOS research. A study of this kind was carried out in 2010. Twenty-three definitions were proposed to the respondents, asking them to indicate to what extent they considered them to be a feature of democracy. The four strongest associations were: equality before the law, equal education opportunities, selection of the best politicians to govern the country, and protection of the personal freedom of citizens. It is worth noting, however, that for at least three-fourths of the respondents, it was also important that the state finances certain areas of life, such as health, education, and culture, and also to ensure the wellbeing of citizens and freedom of expression and organization. In addition, no less than $60 \%$ of the respondents believed that, in a democracy, the state ensures decent living conditions for the poorest, and the government meets the needs of citizens. A similar percentage pointed to importance of an active citizenry, the parliament's representation of the will of citizens, and the state's responsibility for the economy. Considering the results as a whole, we can see a strong attachment among Poles to a social or caring vision of democracy. This assumption was reflected in the results of research conducted in 1995 by the team led by Reykowski (1995), as well as in the results of comparative research conducted among Polish and German students in 2004 (Pająk, 2008).

\section{Data and methodology}

For our research we used the European Social Survey (ESS) R6 data. ESS provides a unique, high-quality dataset. The ESS Round 6 included a list of questions about the understanding of democracy and its evaluation. Europeans from twenty-eight countries were first asked about the importance of selected democratic attributes in general, which makes it possible to create a list of the most important attributes of democracy, thus giving a picture of how citizens understand democracy. The ESS Round 6 was carried out in 2012 (Poland) and 2013 (Czech Republic). Respondents were randomly selected. The data is weighted by design and population size, to reduce possible bias. The total number of respondents in the Czech-Polish dataset is 3,907 (Table 1). 
Table 1

Sample size of the ESS R6 Czech-Polish dataset

\begin{tabular}{||l|c|c|}
\hline \hline & Frequency & Percent \\
\hline Czech Republic & 2009 & 51.4 \\
\hline Poland & 1898 & 48.6 \\
\hline Total & 3907 & 100,0 \\
\hline
\end{tabular}

First, we present some descriptive statistics of the way people understand democracy in the Czech Republic and in Poland. People were asked to rate the perceived importance of sixteen different attributes of democracy on the scale from 0 (= not important at all) to 10 (= very important), for the ideal democracy. Then, we ran a principal component analysis (PCA, rotated solution using Varimax method) which showed us the two most important factors in the way people understand democracy. The PCA method is suitable for detecting the existence of latent factors in the data. Based on the results of the PCA, two indices - the index of pluralism and the social rights index - were constructed. However, the resulting indices do not divide populations into supporters of liberal values in democracy and advocates of social rights. It is clear that every person understands democracy in terms of both of these dimensions, but gives them different weight. Using the two-step cluster technique, ${ }^{1}$ which is more robust to use for large files, we were able to identify similarities in the interpretation of democracy in the sense of representing both of the above-mentioned dimensions.

Both of the dimension indices were used in the regression model as independent variables to test its possible influence on the levels of specific and diffuse support. Specific support was, according to the literature, measured by the SWD question (Satisfaction with the way democracy works in their country), and diffuse support was measured by the level of perceived importance of living in a democratically governed country. In both countries, we can see that the level of diffuse support is higher than specific support. If we compare the data with the rest of the EU countries involved in the research, this result is not surprising. As can be seen in Table 2 for all values, Czechs and Poles are slightly below the European average, and differences in the levels of diffuse support and evaluations of national democracy are statistically significant.

${ }^{1}$ Using the IBM SPSS 24.0 Software. 
Finally, we tested the regression model to establish to what extent these dimensions in the understanding of democracy affect the levels of political interest and political participation.

Table 2

Levels of diffuse and specific support and evaluations of national democracy

\begin{tabular}{|c|c|c|}
\hline \multirow{3}{*}{...live in democratically governed country } & $\overline{\mathbf{C Z}}$ & PL \\
\hline & \multicolumn{2}{|c|}{ Mean } \\
\hline & 7.95 & 8.16 \\
\hline How democratic [country] is overall & 6.20 & 5.87 \\
\hline How satisfied with the way democracy works in [country] & 5.04 & 4.91 \\
\hline
\end{tabular}

\section{The ways of understanding democracy in the Czech Republic and Poland}

At the individual level, it is necessary to distinguish which of the democracies the respondent has in mind when evaluating the performance of the regime. Democracy is an ambiguous concept, and we can expect that people who have different expectations from democracy will also judge it differently.

Table 3

Order of importance of democratic attributes

\begin{tabular}{||l|r|r|}
\hline \multirow{2}{*}{} & CZ & PL \\
\cline { 2 - 3 } & \multicolumn{2}{|c|}{ order } \\
\hline The courts treat everyone the same & 1 & 1 \\
\hline National elections are free and fair & 2 & 5 \\
\hline The media provide citizens with reliable information ... & 3 & 2 \\
\hline The courts are able to stop the government ... & 4 & 4 \\
\hline The government explains its decisions to voters & 5 & 3 \\
\hline Governing parties are punished in elections ... & 6 & 7 \\
\hline The media are free to criticize the government & 7 & 12 \\
\hline Citizens have the final say [...] directly in referendums & 8 & 8 \\
\hline Opposition parties are free to criticize the government & 9 & 13 \\
\hline The government protects all citizens against poverty & 10 & 6 \\
\hline Different political parties offer clear alternatives to one another & 11 & 14 \\
\hline
\end{tabular}

The results suggest that there is something like a general definition of democracy; between the two countries we find significant similarities in 
the understanding of democracy (Table 3). Clearly, the most important attribute of democracy for both Czech and Polish respondents is equality before the courts. While the Czechs ranked free and fair elections second, Poles attached more importance to accountability (reliability of information in the media and the ability of the government to explain its decisions to voters). More significantly, the two countries differ in their respective understanding of the importance of having a democratic debate, and the ability of the opposition and the media to freely criticize the government. Czechs stress more the importance of clear alternatives between parties, freedom to criticize the government etc., which may still be a consequence of the Opposition Agreement. Approximately in the middle we can find the possibility to make decisions in referendums (as an instrument of direct democracy). Although the issue of strengthening the instruments of direct democracy is current in many European countries (especially after the referendum on Brexit ${ }^{2}$ ), it seems that citizens of the Czech Republic and Poland do not perceive it as a typical feature of democracy. Social rights (protection against poverty, reduction of income inequality) are also perceived as less significant for democracy than civil and political rights. On the other hand, Czechs associate the issue of the protection of minority rights with democracy significantly less often, which may also be due to the high degree of atheism in the Czech Republic. At the heart of the question is also the understanding of the term of 'minority,' i.e. what kind of minority the respondent has in mind when answering. In general, however, the low importance attached to the need to protect the rights of minorities is not surprising, and corresponds to the results of other studies of the value orientations of Czechs (Anýžová, 2018).

\section{Liberties or social rights?}

Whether the attributes in question are somehow intertwined and form a latent variable (factor) has been tested using the principle components analysis (PCA). It divides them into two factors (Table 4), interpreting them as a factor of liberalism (free and fair elections, freedom of the opposition to criticize the government, freedom of the media, protection of minority rights, equality before the courts) and

${ }^{2}$ It is necessary to remember that the ESS R6 data was collected before the referendum on Brexit. 
the factor of social equality (reduction of income inequality, protection against poverty). ${ }^{3}$

Table 4

\section{Liberal and social visions of democracy}

\begin{tabular}{||l|c|c||}
\hline \multirow{2}{*}{} & \multicolumn{2}{c||}{ Factor } \\
\cline { 2 - 3 } & $\mathbf{1}$ (liberal) & $\mathbf{2}$ (social) \\
\hline Opposition parties are free to criticize... & 0.828 & \\
\hline The media provide citizens with reliable information... & 0.761 & \\
\hline The media are free to criticize the government & 0.758 & \\
\hline National elections are free and fair & 0.729 & \\
\hline Different political parties offer clear alternatives... & 0.719 & \\
\hline The courts treat everyone the same & $\mathbf{0 . 6 0 1}$ & 0.391 \\
\hline The rights of minority groups are protected & $\mathbf{0 . 5 7 7}$ & 0.310 \\
\hline $\begin{array}{l}\text { The government takes measures to reduce differences in in- } \\
\text { come... }\end{array}$ & & 0.904 \\
\hline The government protects all citizens against poverty & & 0.890 \\
\hline
\end{tabular}

Extraction Method: Principal Component Analysis.

Rotation Method: Varimax with Kaiser Normalization. ${ }^{\text {a }}$

As stated above, both factors only reveal a two-dimensional understanding of the notion of democracy among citizens, but we do not know whether there are groups of people who prefer one or another dimension. Using the two step cluster method, we verified whether groups of people can be identified in the data whose understanding of democracy is similar. The first cluster (C1) is made up of people who generally attribute extremely high importance to both dimensions of democracy and do not consider one significantly more important than the other, with the average value of the dimensions reaching 9.6 (social equality) and 9.3 (liberal d.). ${ }^{4}$ The second cluster (C2), on the other hand, is made up of people who evaluate both dimensions slightly below average, but appreciate the liberal dimension of democracy somewhat more (7.6 vs. 6.6).

When looking at both groups in terms of their characteristics, the first model of the understanding of democracy is particularly characteristic of the Poles (Table 5), people over the age of sixty and those with incomplete or elementary education. On the other hand, both men and women in

${ }^{3}$ All other attributes had mixed effects on the two factors, so we did not include them in further analysis. Scale reliability test: Cronbach's alpha Factor $1=0.855$, Factor $2=0.826$.

${ }^{4}$ According to the confidence intervals the order of dimensions may be reversed. 
both clusters are represented similarly. We can also say that rural dwellers more often understand democracy in the sense of the first model, while people from big cities prefer in democracy the sense of freedom. The results also correspond to the assumption that one attaches more importance to the values that are not so broadly accepted by society (Mishler, Rose, 1999). Therefore, it is not surprising that the understanding of democracy in the sense of the first model is more common among people whose economic situation is difficult, and people who are in an easier financial situation are very often among the other cluster.

Table 5

\section{Characteristics of clusters}

\begin{tabular}{|c|c|c|c|}
\hline & Both C1 & Liberal C2 \\
\hline & & \multicolumn{2}{|c|}{$\begin{array}{l}\text { Row N \% } \\
\end{array}$} \\
\hline \multirow[t]{2}{*}{ Gender } & Male & $62.2 \%$ & $37.8 \%$ \\
\hline & Female & $62.5 \%$ & $37.5 \%$ \\
\hline \multirow[t]{4}{*}{ Age } & $15-29$ years & $54.9 \%$ & $45.1 \%$ \\
\hline & $30-44$ years & $61.8 \%$ & $38.2 \%$ \\
\hline & $45-59$ years & $63.8 \%$ & $36.2 \%$ \\
\hline & $60+$ & $68.7 \%$ & $31.3 \%$ \\
\hline \multirow[t]{3}{*}{ Education level } & ISCED I+II & $66.6 \%$ & $33.4 \%$ \\
\hline & ISCED III $a+b$ & $60.9 \%$ & $39.1 \%$ \\
\hline & ISCED IV+V & $58.2 \%$ & $41.8 \%$ \\
\hline \multirow{4}{*}{$\begin{array}{l}\text { Feeling about } \\
\text { household's } \\
\text { current income }\end{array}$} & Living comfortably & $41.6 \%$ & $58.4 \%$ \\
\hline & Coping & $63.8 \%$ & $36.2 \%$ \\
\hline & Difficult & $66.9 \%$ & $33.1 \%$ \\
\hline & Very difficult & $62.7 \%$ & $37.3 \%$ \\
\hline \multirow[t]{5}{*}{ Domicile } & A big city & $55.5 \%$ & $44.5 \%$ \\
\hline & Suburbs of big city & $59.1 \%$ & $40.9 \%$ \\
\hline & Town or small city & $64.6 \%$ & $35.4 \%$ \\
\hline & Country village & $64.8 \%$ & $35.2 \%$ \\
\hline & Farm or home in countryside & $66.7 \%$ & $33.3 \%$ \\
\hline \multirow[t]{2}{*}{ Country } & $\mathrm{CZ}$ & $39.0 \%$ & $61.0 \%$ \\
\hline & PL & $68.5 \%$ & $31.5 \%$ \\
\hline
\end{tabular}

\section{Regression model}

We decided to test whether the concept of democracy influences the level of specific and diffuse support for the regime. First of all, it is necessary to state that the predictive capacity of the model is unsatisfactory, 
in particular with regard to specific support. The data suggests that the conception of democracy has little influence on the level of satisfaction with democracy in the country. As supposed, the first factor (liberal dimension) influences the levels of satisfaction with democracy in country positively, and the second (social dimension) negatively. Using diffuse support (how important it is to live in democratically-governed country) as a dependent variable, the influence is even higher.

On the other hand, there is no significant difference in the levels of support between the two countries. When controlling for individual characteristics (gender, age, education), ${ }^{5}$ the level of support for liberal values has the most significant influence on the level of specific support. People who stress liberties in democracy are more satisfied with Czech, rather than Polish, democracy than those who evaluate it lower. Surprisingly, we found no influence of gender or age on the levels of specific or diffuse support.

Table 6

Influence of the way people understand democracy on the level of diffuse support for the regime

\begin{tabular}{|c|c|c|c|c|}
\hline & \multirow[t]{2}{*}{ Model } & \multicolumn{2}{|c|}{ Unstandardized Coefficients } & \multirow{2}{*}{$\begin{array}{c}\begin{array}{c}\text { Standardized } \\
\text { Coefficients }\end{array} \\
\text { Beta }\end{array}$} \\
\hline & & B & Std. Error & \\
\hline \multirow[t]{14}{*}{1} & (Constant) & 7.934 & 0.124 & \\
\hline & Gender $(0=$ female $)$ & -0.075 & 0.065 & -0.017 \\
\hline & Age (15-26 ref.) & & & \\
\hline & $30-44$ & 0.111 & 0.094 & 0.022 \\
\hline & $45-59$ & -0.007 & 0.093 & -0.001 \\
\hline & $60+$ & 0.044 & 0.094 & 0.009 \\
\hline & Education (ISCED I+II ref.) & & & \\
\hline & ISCED III $a+b$ & 0.213 & 0.079 & 0.047 \\
\hline & $I S C E D I V+V$ & 0.616 & 0.088 & 0.123 \\
\hline & Country $(0=\mathrm{CZ})$ & -0.019 & 0.087 & -0.003 \\
\hline & Understanding of democracy & & & \\
\hline & Liberalism & 1.118 & 0.05 & 0.366 \\
\hline & Social equality & -0.102 & 0.039 & -0.043 \\
\hline & $\mathbf{R 2}$ & & 0.144 & \\
\hline
\end{tabular}

Dependent variable: How important is it for you to live in democratically governed country. Note: Indices of liberalism and social equality are based on the results of PCA, the values are $\mathrm{Z}$ score standardized.

5 Subjective feeling about household income level was ignored in the model due to high collinearity levels. 
Many scholars consider civic engagement to be a prerequisite for democratic stability and, at the same time, we know from previous research that people who are politically active are more satisfied with the workings of the democratic regime than those who are inactive. It is important to find out whether conception of democracy is related to the degree of political activity. Nevertheless, controlling for gender, age and education, we have found that the influence of the way democracy is understood on participation in elections and degree of political interest is marginal. ${ }^{6}$ The degree of political interest and political activity is therefore determined by other factors.

\section{Discussion}

The assumptions adopted in the introduction were confirmed by the analysis. According to the first hypothesis, Poles and Czechs understand the concept of democracy in a different way. It should be emphasized, however, that the differences observed are related to the different distribution of associations with individual statements. The Poles who were surveyed during the research more often associated the concept of democracy with statements regarding the social sphere and expectations towards the state. This is in accordance with findings observed in earlier studies. Seeking explanations for this result, one could, following the explanations used by other researchers, point to the influence of experiences with an undemocratic system. It could have raised the expectations of Poles towards the state in terms of social security. However, this is not entirely satisfactory if we take into account the fact that Czech society has also experienced life in an undemocratic system. Nevertheless, the association of democracy with its social aspects was weaker among them. Perhaps it should be taken into account that the Czech Republic has, unlike other countries in the region, including Poland, a "special historical heritage" in the form of a parliamentary democracy which functioned from the time when the Czechoslovakian Republic was established in 1918 until the Munich Agreement in 1938. In turn, the communist regime "was one of the most unpleasant and harsh," and the Czech Republic "consistently displays the lowest positive rating of the former communist regime from all new EU member states" (Leff, 2012, pp. 192-193). Apart from the influence of socialization in the communist

\footnotetext{
${ }^{6}$ These results are not presented, only commented.
} 
regime, it seems that attitudes to the role of the state in the social security of the population are affected by the real distribution of income in society. It is true that the greater the income differentials and the higher the poverty risk, the greater the perceived importance of these attributes to citizens (Pospiśilová, 2018). It should also be noted that Czech society is one of the most secular in the world, while the level of religiosity of Poles, though gradually decreasing, is one of the highest in Europe (see Boski, 2009). Other explanations could be provided by the concept of the humanitarian orientation of Polish culture, which originally meant intense interpersonal relations, care and concern for other people, and now includes seven factors: gentleness, understanding, charity, pro-social sensitivity, friendship, patriotism and justice (Boski, Baran, 2018). This dimension, strongly present in Polish culture and appreciated by Poles, may explain the stronger attachment of Poles to the social aspects of democracy. As indicated by Boski, it is not true that the humanitarianism of Polish culture is in contradiction with democracy (unless one focuses exclusively on its liberal understanding), because "the social democratic system of the welfare state, present in many EU countries, limits the market's rights in the redistribution of national income, without diminishing the democratic political system. Humanitarianism is located in such a systemic constellation" (Boski, 2009, p. 393).

The second hypothesis adopted in the introduction gained partial confirmation. It was shown that people who understand democracy through the prism of freedom (libertarian) are more satisfied with functioning of democracy than those who also connect it with social values. On the other hand, it was shown that there are no statistically significant differences in the perceived level of legitimacy of the system between Poland and the Czech Republic, despite the fact that Poles more strongly associate democracy with social characteristics.

It can therefore be concluded that conception of democracy is not the most important factor related to support for the system. This allows us to suppose that there are other, more important factors responsible for differences in this area. It is also worth recalling the opinion of Magalhães, who commented on his own analysis of conditions of support for a democratic system. He points out that "fundamental preferences about regimes are, in fact, greatly influenced by performance” (Magalhães, 2014).

He also emphasizes that research into sources of support for democratic systems requires more precise methods and more careful use of available data. 
The analysis carried out did not show any statistically significant differences between the analyzed societies regarding the level of perceived legitimacy of the democratic system, both in terms of diffuse legitimacy and specific legitimacy.

The only variable that affected the level of the perceived legitimacy of the system in a specific dimension was satisfaction with one's own economic situation. In this case, the result is not surprising, indicating that the level of perceived system legitimacy is lower among people dissatisfied with their own economic situation. Other variables, such as gender, education and place of residence did not affect the way in which democracy was understood, or the level of perceived system legitimacy.

The analyzed research confirms the importance of cultural factors, including historical experiences, in shaping democratic attitudes and beliefs. The results also allow us to suppose that the lack of such experiences may hinder the development of democracy in a given society (see also Inglehart, 2000; Leff, 2018). In the case of the countries that were included in the study, the differences found were not significant, which is probably due to the fact that they do not differ much in terms of culture, although some differences between them have been identified. In Inglehart's study of 2008, Poland and the Czech Republic differed in terms of orientation regarding materialistic values of individualism vs. community (Poles were closer to the middle of the spectrum, while Czechs were closer to the self-expression). However, in Schwartz's research (2010) the differences between the two societies turned out to be small, especially regarding the issue of traditionalism vs. postmodernism (Boski, Baran, 2018). They share similar experiences resulting from living under an undemocratic system, which, regarding the research results described in the article, may be particularly important.

\section{Bibliography}

Andersen R. (2012), Support for democracy in cross-national perspective: The detrimental effect of economic inequality, "Research in Social Stratification and Mobility," 30(4), pp. 389-402, https://doi.org/10.1016/j.rssm.2012.04.002.

Anýžová P. (2018), Čeho si Češi váži a jaké hodnoty dnes preferuji??, in: Jak se žije Čechưm v současné Evropě?, eds. J. Pospíšilová, E. Krulichová, Academia, Sociologický ústav AV ČR, Praha, pp. 13-36.

Baviskar S., Malone M. F. T. (2004), What Democracy Means to Citizens - and Why It Matters, "European Review of Latin American and Caribbean Studies," 76, pp. 3-23. 
Brokl L., Seidlová A., Bečváŕ J., Rakušanová P. (1999), Postoje československých občanů $k$ demokracii v roce 1968 (no. 99:8), Praha.

Boski P. (2009), Kulturowe ramy zachowań społecznych. Podręcznik psychologii międzykulturowej, chapter 10, Wydaw. Naukowe PWN, Academia. Wydaw. SWPS, Warszawa.

Boski P., Baran M. (2018), Polska na kulturowej mapie Europy - Orientacja humanistyczna $w$ kulturze polskiej, in: Podzielony umyst społeczny. Polacy po ćwierćwieczu demokracji, ed. M. Drogosz, Wydaw. Stowarzyszenia Filomatów, Warszawa.

CBOS (2017), Polacy o demokracji, Komunikat z badań CBOS (14/2017), Warszawa.

CBOS (2017), Opinie o demokracji, Komunikat z badań CBOS (118/2017), Warszawa.

CBOS (2017), Zasady demokracji $i$ ich realizacja $w$ Polsce, Komunikat z badań CBOS (107/2017), Warszawa.

CBOS (2018), Opinie o demokracji, Komunikat z badań (75/2018), Warszawa.

CVVM (2018), Názory české společnosti na úroveñ demokracie a respektování lidských práv v ČR - únor 2018, Tisková zpráva CVVM, Sociologický ústav AV ČR, v.v.i., Praha.

Dahl R. A. (2001), O demokracii: průvodce pro občany (1st ed.), Portál, sro, Praha.

Easton D. (1975), A Re-assessment of the Concept of Political Support, "British Journal of Political Science," 5(4), pp. 435-457, https://doi.org/10.1017/ S0007123400008309.

ESS Round 6: European Social Survey Round 6 Data (2012), Data file edition 2.3. NSD - Norwegian Centre for Research Data, Norway - Data Archive and distributor of ESS data for ESS ERIC.

Inglehart R., Catterberg G. (2002), Trends in Political Action: The Developmental Trend and the Post-Honeymoon Decline, "International Journal of Comparative Sociology," 43(3-5), pp. 300-316, https://doi.org/10.1177/002071520204300305.

Inglehart R. (2000), Kultura a demokracja, in: Kultura ma znaczenie, eds. L. E. Harrison, S. P. Huntington, Zysk i S-ka, Poznań.

Karp J. A., Banducci S. A., Bowler S. (2003), To Know it is to Love it?: Satisfaction with Democracy in the European Union, "Comparative Political Studies," 36(3), pp. 271-292, https://doi.org/10.1177/0010414002250669.

Kornberg A., Clarke H. D. (1994), Beliefs About Democracy and Satisfaction with Democratic Government: The Canadian Case, "Political Research Quarterly," 47(3), pp. 537-563, https://doi.org/10.1177/106591299404700301.

Kunštát D. a kol. (2014), 25 let české demokracie očima veřejnosti (1st ed.), Academia, Sociologický ústav AV ČR, v.v.i., Praha.

Leff C. S. (2012), Tworzenie wartości demokratycznych $w$ Republice Czeskiej po 1989 r., in: S. P. Ramet, Polityka Europy Środkowej i Południowo-Wschodniej po 1989 r., Książka i Wiedza, Warszawa. 
Linek L. (2016), Legitimacy, Political Disaffection and Discontent with (Democratic) Politics in the Czech Republic, "Acta Politologica," 8(2), pp. 51-73.

Lyons P. (2013), Adjectives of Democracy: Citizenship and Political Attitudes Under Socialist and Liberal Democracy in the Czech Republic, Sociologické nakladatelství (SLON), Praha.

Magalhaes P. C. (2014), Government effectiveness and support for democracy, "European Journal of Political Research," 53, pp. 77-97, doi: 10.1111/14756765.12024.

Mansfeldová Z. (2006), The Czech Republic: Critical democrats and the persistence of democratic values, in: Democracy and Political Culture in Eastern Europe, eds. H.-D. Klingemann, D. Fuchs, J. Zielonka, Routledge, Milton ParkAbingdon, pp. 102-118.

Miller, A. H., Hesli, V. L., \& Reisinger, W. M. (1997). Conceptions of Democracy Among Mass and Elite in Post-Soviet Societies. British Journal of Political Science, 27(2), 157-190. https://doi.org/10.1017/S0007123497000100.

Mishler W., Rose R. (1999), Five Years After the Fall: Trajectories of Support for Democracy in Post-Communist Europe, in: Critical Citizens. Global Support for Democratic Government, ed. P. Norris, Oxford University Press, Oxford, pp. 78-99.

Mlejnek J. (2015), Kuře v hrnci a křeček v kole: česká politika a její transformace $v$ kontextu civilizačni krize, $\mathrm{CDK}$, Brno.

Neundorf A. (2010), Democracy in Transition: A Micro perspective on System Change in Post-Socialist Societies, "The Journal of Politics," 72(4), pp. 1096-1108, https://doi.org/10.1017/S0022381610000551.

Pająk B. (2008), Demokracja polska i niemiecka. Tradycja, teraźniejszość, przyszłość, Wydawnictwo INPiD UAM, Poznań.

Pospíšilová J. (2018), Rozuměji Češi demokracii?, in: Jak se žije Čechưm v současné Evropě?, eds. J. Pospíšilová, E. Krulichová, Academia, Sociologický ústav AV ČR, Praha, pp. 107-126.

Reykowski J. (1995), Potoczne wyobrażenia o demokracji. Psychologiczne uwarunkowania i konsekwencje, Wydaw. IPPAN, Warszawa.

Svolik M. W. (2013), Learning to love democracy: Electoral accountability and the success of democracy, "American Journal of Political Science," 57(3), pp. 685-702, https://doi.org/10.1111/ajps.12005.

Thomassen J. (1998), Support for Democratic Values, in: Citizens and the State, eds. H.-D. Klingemann, D. Fuchs, Oxford University Press, Oxford, pp. 383-416.

\section{Czeskie i polskie rozumienie demokracji}

\section{Streszczenie}

Celem artykułu była analiza wyników badań przeprowadzonych w ramach European Social Survey Round 6 (2012, 2013) w części dotyczącej rozumienia demokra- 
cji w Polsce oraz w Czechach. Interesowały nas różnice w definiowaniu demokracji występujące pomiędzy obu krajami oraz ich konsekwencje dla legitymizacji systemu, a także czynniki demograficzne różnicujące sposób rozumienia demokracji w obrębie obu badanych grup. Zastosowane analizy statystyczne wykazały istnienie różnic w definiowaniu demokracji pomiędzy Polską a Czechami (Czesi mocniej podkreślali liberalne aspekty demokracji, natomiast Polacy - socjalne). Jednak zaobserwowane relacje pomiędzy sposobem definiowania demokracji a poziomem legitymizacji systemu demokratycznego w obu wymiarach (dispersed and specific legitimacy) okazały się stosunkowo słabe. Podobnie jak zależności pomiędzy sposobem rozumienia demokracji i legitymizacji systemu demokratycznego a czynnikami społeczno-demograficznymi. Jedynie poziom zadowolenia z własnej sytuacji materialnej badanego okazał się czynnikiem istotnym dla poziomu legitymizacji systemu demokratycznego.

Słowa kluczowe: rozumienie demokracji, demokracja, Polska, Czechy 